\title{
地すべり変位速度の指数関数的低減現象
}

\section{Exponential decrease phenomenon of the landslide displacement velocity}

\author{
神原規也 ${ }^{\mathrm{a}) *}$ \\ Noriya KAMIHARA
}

\begin{abstract}
Landslides during the deceleration phase tend to exponentially decrease their displacement velocities. Such phenomena suggest the exponential reduction of the factor concerning rainfall as a cause of the landslide instability. It is expected that indices of the landslide stability can be estimated by the rainfall intensity. An approach to evaluate the correlation between the landslide displacement velocity and the tank model storage depths was reported recently". This indicates that landslide stability indices can be obtained directly from precipitation. Here the author reports a case where primary, secondary and tertiary creeps were discriminated respectively by the ratio between the displacement velocity and the tank model storage depths. On the other hand, the primary creep sometimes occurs regardless of the factor concerning rainfall. This phenomenon indicates the temporal change to increase "the strength of slide surface" in the active landslide.
\end{abstract}

Key words : landslide displacement velocity, exponential decrease, primary creep, tank model, rheology

\section{和文要旨}

滑動中の地すべりにおいて，地すべり変位速度は減速域では指数関数的低隇傾问を示すことがある。この原因には，降雨に田来 する地すべり不安定化要因の指数関数的低減が挙げられる。この評価手法として, 地すべり変位速度とタンクモデル䝪留高の相関 関係も指摘されている”。このことは，降水量から直ちに地すべり安定度の指標が得られることを意味する。本論文では阔者の比率 から 1 次, 2 次, 3 次クリープの識別事例の報告を行う。一方, 降雨による要因とは無関係に 1 次クリープ的現象が生じている場 合が有り, 滑動中の地すべり地における「すべり面強度」の経時的增加の可能性を示唆する。

キーワード：地すべり変位速度, 指数関数的低減, 1 次クリープ, タンクモデル, レオロジー

\section{1.はじめに}

地すべり変位速度の検討対象を急速な流下現象を除く 時速数十 $\mathrm{cm}$ 程度以下までに絞ると, 運動エネルギーの 地すべり変位速度に与える影響は無視しうる值である。 このような緩速な移動・変形を呈する地すべり現象の変 位速度変動メカニズムを, レオロジーの面から解明しよ うという試みは古くから行われ(2).314)，3次クリープから 崩壊に至る過程の解析を通じて崩壊時刻の予測を試みた 斎藤に始まる手法 ${ }^{5)(6)}$ な゙の成果も得られている。しか し, 大半の地すべり地においては, 破局的な崩壊に至る ことなく一旦停止し，あるいは更に滑動を繰り返すと いった複雑な動きを見せている。滑動中の地すべりがい つ停止するのかという問題は, 警戒避難態勢の解除など の判断に不可久であり,さらになぜ, どのようにして停 止するのかというメカニズムの解明は, 地すべりの抑止 や抑制の検討にも関連する基本的な課題の一つである。

断続的な滑動を繰り返しているように見える地すべり 現象も, 地すべりの変位速度に着目すると一定の規則性 を示していることがある。特に地すべり変位速度の減速 域においては指数関数的低減傾向を示す事例が認められ る。まとまった降雨の度に滑動と停止を繰り返すような 地すべりが, 減速域では指数関数的低減傾问を示し,さ らにタンクモデルの貯留高と一定の相関性を示す事例の あることが指摘されている

\footnotetext{
* 連絡著者/corresponding author

a）株式会社エイトコンサルタント和歌山支店技術部

EIGHT CONSALTANTS CO.. LTD.

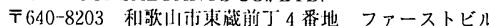

4 Higashikuramaechou Wakayama City 640-8203. Japan
}

地すべり抵抗力： $\Sigma N$ を上回る際の応力の值を差応力： $\sigma(\sigma=\Sigma T-\Sigma N)$ と定義すると, この差応力の地すべり 変位速度に及ぼす影響が，降雨の停止に伴い指数関数的 に低減していることを示している。一方，降雨に起因す る要因とは無関係に，また地すべり移動体の全体形状の 顕著な変形も伴わずに，地すべり変位速度が指数関数的 に低減し，時に地すべりの停止にまで至る 1 次クリープ 的現象が生じる事例も見られる。このような現象の説明 には，移動中の地すべりにおけるトータルとしての「す ベり面強度」の経時的な增加を要因の一つに挙げる必要 がある。

ところで近年, 自動観測システムの普及に伴い, 高い 測定精度の観测デー夕を密な時間間隔で取得することが 容易になり，このような地すべり変位速度の変化と降水 量, さらには地下水位相互の関係をより詳細に把握する ことが可能となっている。この降水量から直接算出され る值であるタンクモデル貯留高は, 地すべり変位速度と の間に一定の相関性を示すことがあることから，この夕 ンク貯留高を指標に加え，これら相互の相関関係の検討 を行い, レオロジー面からの評価の可能性について検討 を行った。

なお,「地すべり移動速度」という表現は, 地すべり が一体化して等速度の移動・変形を生じているという印 象を与えるが, 地すべり現象に伴う地すべり移動体の変 形は必ずしも頭部から末端部まで一様でない場合がある。 ここでは「地すべり変位速度」という表現を用いること とし, 特に断らない場合には通常最も変位量の大きな地 
すべり冠頭部において，地盤伸縮計などで観測された地 すべりの変位速度を用いることとした。

\section{2. 地すべり地の概要}

本検討に用いた地すべり地の概要を表ー 1 に示す。

\subsection{S地区}

S地区は徳島県東南部の国道沿いに発生した地すべり で，ブロック側方部の吹き付け法面の小崩壊に伴い，頭 部の亀裂が発見されたものである。小崩壊発生の10日ほ ど前に $80 \mathrm{~mm}$ 程度の日雨量を記録しているが，その後目 立った降雨には見舞われず，無降雨時に突然法面の一部 が崩壊し，この背後の地すべり性の亀裂が発見された。 地すべり発見後直ちに冠頭部に伸縮計を設置し観測を開 始した。S地区は常時 $1 \sim 2 \mathrm{~mm} / \mathrm{d}$ 以上の基底的な地す ベり変位速度を保ちつつも, 降雨の度に地すべり変位速 度の増減を繰り返し, 最終的には 3 次クリープ領域を経 て崩壊に至っている。

\subsection{T地区}

T地区は紀伊半島を東西に横切る中央構造線に沿って 伸びる紀ノ川の南部約 $1.5 \mathrm{~km}$ に位置している。標高 300 〜 $500 \mathrm{~m}$ 程度のなだらかな段丘状の広大な丘陵斜面の側 方部に形成された崩積土層地すべりで，梅雨期の豪雨を 契機に顕在化した地すべりである。T地区の地すべりは 平常時には停止しているものの, 降雨に伴い地すべり変 位速度の著しい増減が生じたもので, 孔内水位と地すべ り変位速度にも一定の相関関係が認められた。

\subsection{Y地区}

Y地区はT地区の東北東約 $18 \mathrm{~km}$ 付近に位置する，紀ノ 川南岸支流沿いの地すべり地である。地すべり深度の浅 い小規模な崩積土地すべりあるが，すべり面は $40^{\circ}$ 弱の かなり急な勾配を有している点が特徵的である。地すべ りブロック末端部の掘削に伴い地すべり現象が急速に活 発化したもので，直ちに掘削部分を埋め戻すとともに， 大型土のう（通称トン袋）による抑え盛土工を 4 〜 段 にわたって実施し，同時に地盤伸縮計による監視を開始 した。Y地区は定常的な地すべり変位速度を保ちつつ, 降雨時には地すべり変位速度の著しい増減を見せていた が，この過程で明瞭な 1 次クリープ及び歪硬化的現象が 見られている。

表一 1 地すべりの概要

Table 1 Outline of landslides

\begin{tabular}{|c|c|c|c|c|}
\hline \multicolumn{2}{|c|}{ 地 区 名 } & $\begin{array}{l}\text { 徳 島 県 } \\
\mathrm{S} \text { 地 区 }\end{array}$ & $\begin{array}{c}\text { 和 歌山県 } \\
\mathrm{T} \text { 地 区 }\end{array}$ & $\begin{array}{c}\text { 和 歌山県 } \\
\text { Y 地 区 }\end{array}$ \\
\hline \multicolumn{2}{|c|}{$\begin{array}{c}\text { 地すべりの } \\
\text { タイプ }\end{array}$} & $\begin{array}{c}\text { 初生的岩盤 } \\
\text { 地すべり }\end{array}$ & $\begin{array}{l}\text { 崩 積土層 } \\
\text { 地すべり }\end{array}$ & $\begin{array}{l}\text { 崩積土層 } \\
\text { 地すべり }\end{array}$ \\
\hline \multicolumn{2}{|c|}{ 基盤地質 } & $\begin{array}{c}\text { 秩父帯 } \\
\text { 頁岩主体層 }\end{array}$ & $\begin{array}{c}\text { 三波川帯 } \\
\text { 結晶片岩類 }\end{array}$ & $\begin{array}{c}\text { 三波川帯 } \\
\text { 結晶片岩類 }\end{array}$ \\
\hline \multirow{3}{*}{$\begin{array}{l}\text { り地 } \\
\text { 模のす } \\
\text { 規べ }\end{array}$} & $\begin{array}{l}\text { 斜 面 } \\
\text { 長 }\end{array}$ & $50 \mathrm{~m}$ & $110 \mathrm{~m}$ & $40 \mathrm{~m}$ \\
\hline & 幅 & $40 \sim 50 \mathrm{~m}$ & $40 \sim 70 \mathrm{~m}$ & $22 \mathrm{~m}$ \\
\hline & $\begin{array}{l}\text { 平均 } \\
\text { 層厚 }\end{array}$ & $13 \mathrm{~m}$ & $5 \mathrm{~m}$ & $3 \mathrm{~m}$ \\
\hline \multicolumn{2}{|c|}{$\begin{array}{l}\text { すべり 面 } \\
\text { 平均勾 配 }\end{array}$} & $40^{\circ}$ & $18^{\circ}$ & $40^{\circ}$ \\
\hline
\end{tabular}

3. 降雨に起因して活発化した地すべりにおける降雨後 の地すべり変位速度の指数関数的低減現象

3.12 次クリープ段階の地すべりにおける降雨に起 因する地すべり変位速度の指数関数的低減現象 (S地区の事例)

2 次クリープ段階にある地すべりは，本来基底值とし ての定常的な変位速度を有しているが，これに降雨の影 響が加わり地すべり変位速度が大きく変化する場合があ る。

図ー 1 に示されるように，まとまった降雨の度に急増 した地すべり変位速度は，その後無降雨期間が続く限り 一定の割合で減速し，片対数グラフ表示で直線状の変位 速度低下として現れる指数関数的低減傾向を示すことが ある。このような歪速度の指数関数的低減を説明する基 本的なレオロジーモデルには，通常図一 2 に示すフォー クトモデルがまず挙げられるが，降雨のたびに幾度も指 数関数的低減傾向を示す現象をフォークトモデルで代表 されるような単純な 1 次クリープ現象として説明するこ とはできない。

ところで，図－39模式図に示されるタンクモデル各 段の貯留高 $(h 1 \sim h 4)$ は, 降雨によってタンク内に貯留 された水が貯留高に比例した一定の割合で流出孔や浸透 孔から流出するというメカニズムを有し，降雨による供 給が停止すると各段のタンク貯留高は指数関数的に低減 する。図 - 1 に示されるS地区の地すべり変位速度も, 降雨を契機に幾度も上昇した後の低減域では, その度に 同様な指数関数的低減傾向を示し両者の相関関係を予想

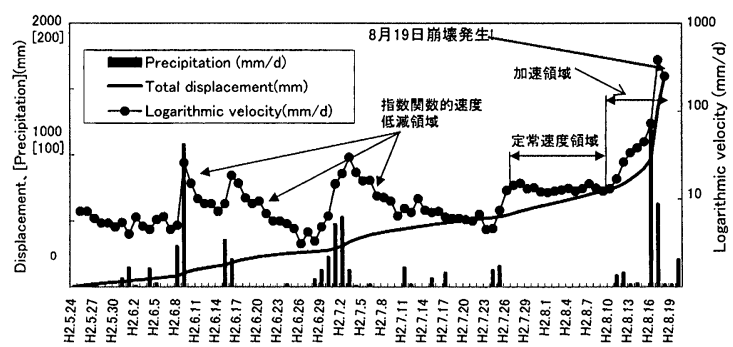

図－1Ｓ地すべり 降水量，移動量，対数表示地すべり 変位速度図

Fig. 1 Change of precipitation, total displacement and logarithmic velocity in S-Landslide

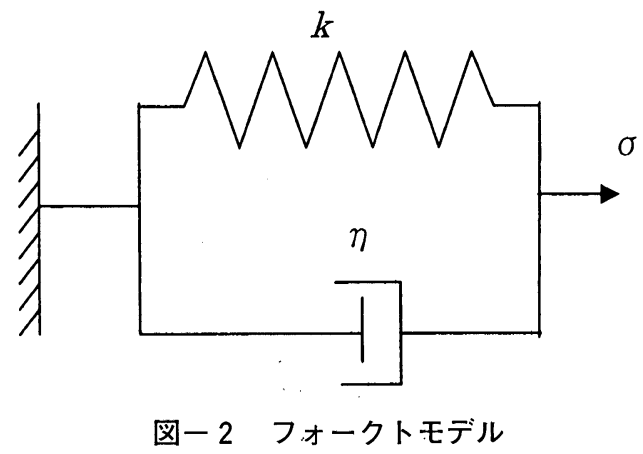

Fig. 2 Voigt model 
させる。しかし, 菅原によって長短期の流出解析のため に考案されたタンクモデルは，本来実測された流出量か らの逆算によって各定数が同定されるものであり，タン クモデル販留高と地すべり変位速度の比較を行う場合, この定数の設定方法が問題となる。ここでは，まず菅原 が長期流出解析の出発点として用いているタンクモデ ル7の各定数をそのまま用い，最上段から下段へ順次各 段の合計貯留高を求め, 地すべり変位速度との比較を 行った。この過程を図ー4の最上段グラフに，1段目及 び上部から 2〜4段目までのそれぞれの合計䝪留高をい ずれも片対数表示したものを図 - 4の 2 段目のグラフに 示す。ついで，これらの幾つかのモデル中から一定の相 関関係が認められるモデルを試行錯誤の末に求め，4段 目までの合計貯留高と地すべり変位速度を重ねあわせた ものを図ー4の3 段目に示す。ここに示されるように「相 関性の高い期間」とされる期間，この両グラフはほぼ相 似形を示し，また地すべり変位速度 $(V)$ と 4 段目までの タンク合計貯留高 $(H)$ の比率 $(V / H)$ も一定の範囲に収 まり，図-5-a，図-5-bに示すように相関係数は両対 数散布図で $R=0.887$, 通常の散布図でも $R=0.888$ とい う相関関係が得られている1。

ここではタンク合計貯留高が，2次クリープ領域にあ る地すべりにおける降雨による不安定化要因である差応 力のの指標となっていると考えられる。

なお，この事例では流域の実測流量からの逆算によっ て求められたタンクモデル定数は菅原のモデルと大きく
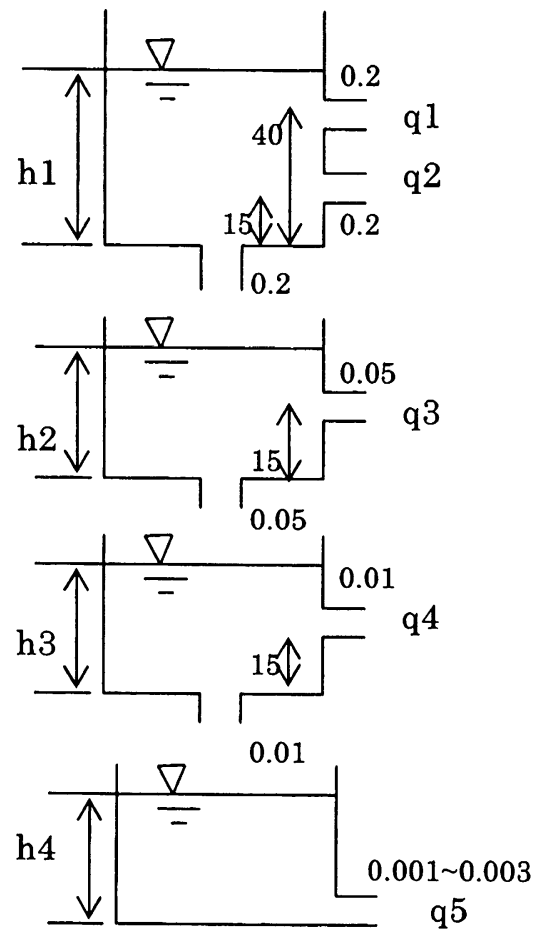

図ー3 菅原のタンクモデル

Fig. 3 Sugawara's tank model h1, h2, h3, h4: Storage depth q1, q2, q3, q4, q5: Run off
異なるものの, 地すべり変位速度と 4 段目までのタンク モデル合計譻留高の間には同程度の相関性が得られてい る ${ }^{1)}$ 。検討対象地の流域の実測流量が得られない場合で も，菅原のモデルのような一般值によって，地すべり変 位速度との間に一定の相関性が認められる可能性があ $り^{1)}$, 本研究で用いるタンクモデルの諸定数は，この菅
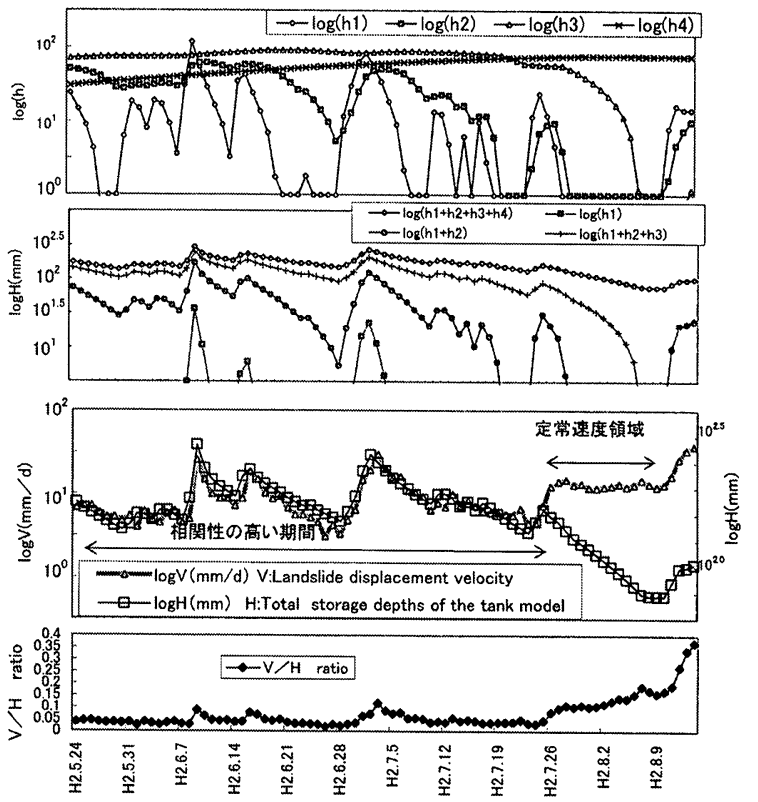

図一 4 S地すべり $\log V-\log H$ 比較図

Fig. 4 Correlation between $\log V$ and $\log H$ in S-Landslide

$\mathrm{V} ：$ 地すべり変位速度 $(\mathrm{mm} / \mathrm{d})$ または $(\mathrm{mm} / \mathrm{h})$

$\mathrm{H}$ : タンクモデル合計貯留高 $(\mathrm{mm}), \mathrm{H}=\mathrm{h} 1 \sim \mathrm{h} 1+\mathrm{h} 2+\mathrm{h} 3+\mathrm{h} 4$ h1, h2, h3, h4：タンクモデル上段から各段の貯留高 $(\mathrm{mm})$

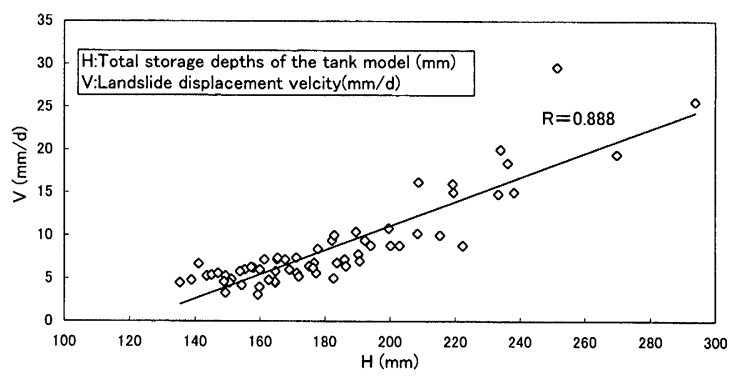

図一-5-aＳ地すべり $V-H$ 相関図

Fig. 5-a $\quad V-H$ diagram of $S$-Landslide

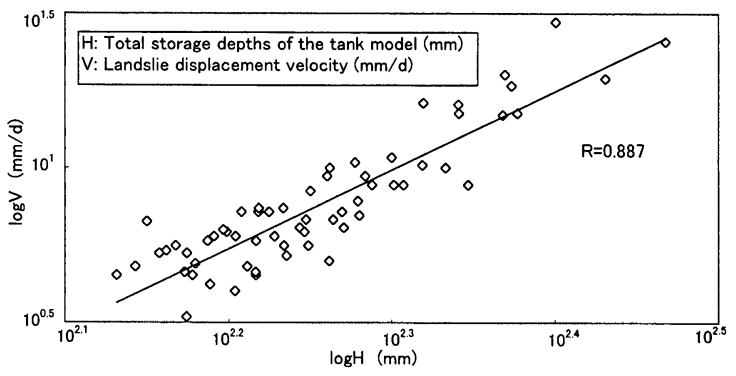

図一-5-b S地すべり $\log V-\log H$ 相関図

Fig. 5-b $\log V-\log H$ diagram of S-Landslide 
原のタンクモデルなどの一般値を用い，最上段からの合 計貯留高を順次用い，最も高い相関性の選られるタンク モデルを用いて検討を行う事とした。

なお，S地すべりでは図－4の「相関性の高い期間」 以後の期間は，地すべり変位速度が急加速する前の段階 において，タンクモデルの合計貯留高の対数表示值 $\log H$ は指数関数的低減傾向をみせる一方で地すべり変 位速度の対数表示值 $\log V$ は定常的の速度を維持し，図 - 4 下段のグラフに示されるように $V / H$ の比率が増大 してゆく過程として 3 次クリープ領域の初期段階が明暸 に現れている。

\section{2 降水量・地すべり変位速度・孔内水位に一定の 相関性が認められる事例（T地区）}

前述のS地区は観測期間を通じて孔内水位が形成され ることは無く，地すべり移動地塊のほとんどは不飽和状 態にあったと考えられる。次いで，すべり面周辺が常に 飽和状態にあったと考えられ，降雨と地すべり変位速度・ 孔内水位の間に一定の相関関係の認められた事例につい て検討を行う。

\subsection{1降水量と地すべり変位速度の相関関係}

地すべりの移動状況の監視には全自動観測方式の伸縮 計を用い， 1 時間毎の変動量を $0.2 \mathrm{~mm}$ の精度で観測し た。図ー6に示されるように，S地区とは異なり，観測 期間を通じて断続的に 2 回の大きな変動を見せている。 8月10日21：00〜 8月14日6:00にかけては $15.4 \mathrm{~mm}$, 9 月21日 $4: 00 \sim 9$ 月23日 $4: 00$ にかけては $70.8 \mathrm{~mm}$ の伸

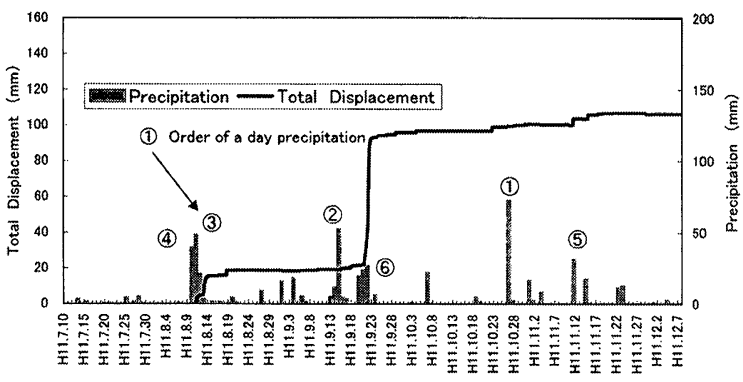

図一6 T地すべり 地盤伸縮計変動図

Fig. 6 Change of precipitation and total displacement in T-Landslide

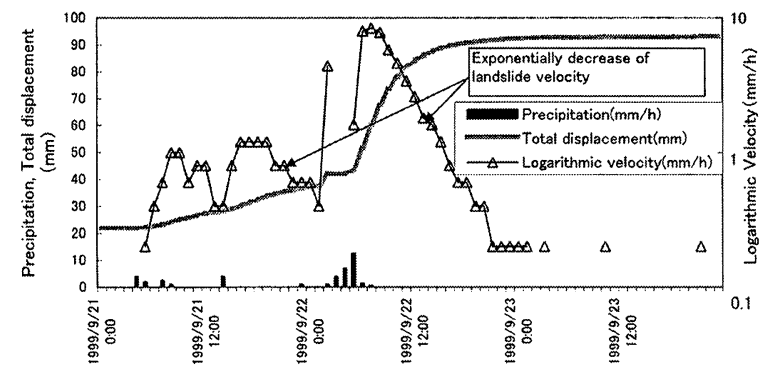

図一７地すべり 降水量, 移動量, 対数表示地すべり 変位速度図

Fig. 7 Change of precipitation, total displacement and logarithmic velocity in T-landslide
び変動を見せている。一方で観測期間を通じての最大日 雨量72mmを示す10月27日には殆ど動きを見せていない。 最も大きな動きを見せた 9 月 22 日の日降水量 $26.5 \mathrm{~mm}$ 図一 6 に○囲みの数字で順位が示されるように観測期間 を通じて 6 番目のものであり，ここでは地すべりの安定 度は日降水量だけでの評価は出来ない。

次いで，最大の変位を示した 9 月 22 日における対数表 示した 1 時間毎の地すべり変位速度と時間降水量の状況 を図 - 7 に示す。地すべり変位速度は最大時間雨量 12.5 $\mathrm{mm} / \mathrm{h}$ 記録した 9 月22日 $4: 00$ 5 : 00の直後である $5: 00$ ：00には $8.0 \mathrm{~mm} / \mathrm{h}$ へと急激に上昇し，6:00〜 $7: 00$ 0. $4 \mathrm{~mm} / \mathrm{h}$ をピークにして，その後は降雨の停止 と共に対数表示でほぼ直線状に低減する明瞭な指数関数 的低減傾向を見せている。

\subsection{2 降水量と孔内水位の相関関係}

1) 孔内水位の変動状況

当地区では図 - 8 の断面図中のBV-1, BV-3に併設し て深度 $7 \mathrm{~m}$ の水位観測孔を設け，地すべり発生から約 5 ケ月にわたって孔内水位の観測を実施した。観測は水 圧式の半自動観測を用い，毎正時の孔内水位を記録した。 観測期間を通じた日変動結果を図ー 9 にまとめる。

冠頭部に設置されたBV-1孔は降雨に対する反応はや や鈍く，10月下旬以降は水位変動を示さなくなった。一 方，地すべりブロック中央部に設置されているBV-3孔 の孔内水位は観測期間を通じ，降雨に敏感に反応して上 下している。また，図－9に○囲みの数字で示されるよ うに，地すべりが最も大きな動きを見せた 9 月 22 日に最 も高い孔内水位を記録している。

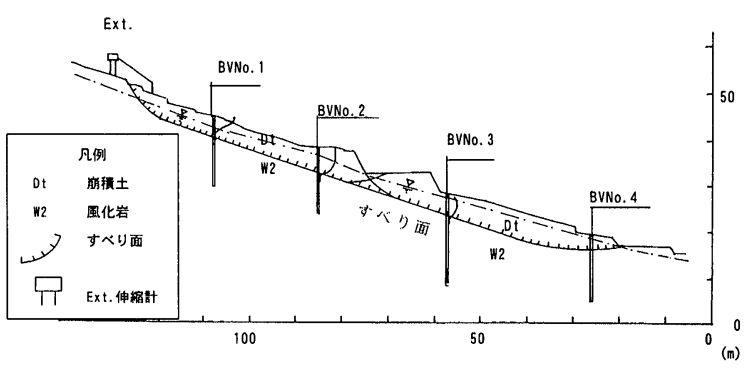

図ー8 T地すべり断面図

Fig. 8 Geologic profile of T-Landslide

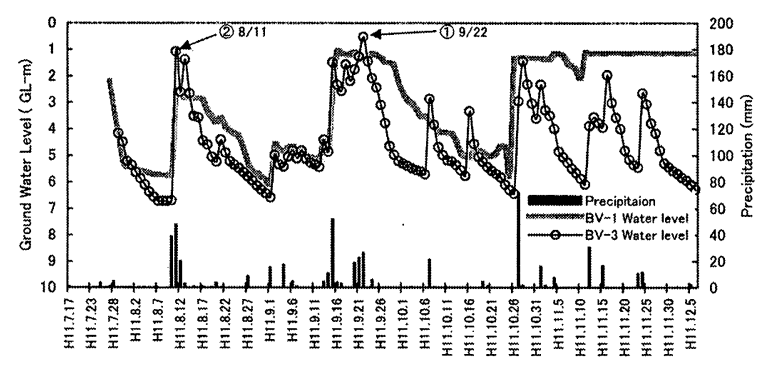

図一 9 T地区水位変動グラフ

Fig. 9 Change of ground water level in T-Landslide 
2) 日単位の孔内水位とタンク合計貯留高の相関関係

図一 9 に示されるように，孔内水位についても当日だ けでなく数日前からの雨量も影響していることが推定さ れる。この影響の評価手法として，同様に菅原のタンク モデルの各段ごとの貯留高（図－10上段グラフ）, 合計 販留高（図一-10中段グラフ）と孔内水位の比較を行った。 図－10下段グラフはBV-3孔の孔内水位とタンクモデル 貯留高を片対数表示でなく, 通常のグラフ表示で重ね合 わせたものである。この最上段のグラフに示されるよう に， 1 段目のタンク眝留高は 8 月11日のものがもっとも 高いが，9月22日に最も高い合計䝰留高を示すモデルは 3 段目までの合計貯留高となる。さらに図ー10下段のグ ラフに示されるようにBV-3孔の孔内水位と 3 段目まで のタンク合計譻留高の日変動パターンは概ね相似形を示 している。また，この両者は図ー11に示されるように相 関係数 $R=0.857$ の線形相関性を示している。

\subsection{3 地すべり変位速度とタンクモデル合計貯留高}

降水量から得られるタンクモデル貯留高は 1 日単位で は図－10下段グラフに示されるように，3段目までの合

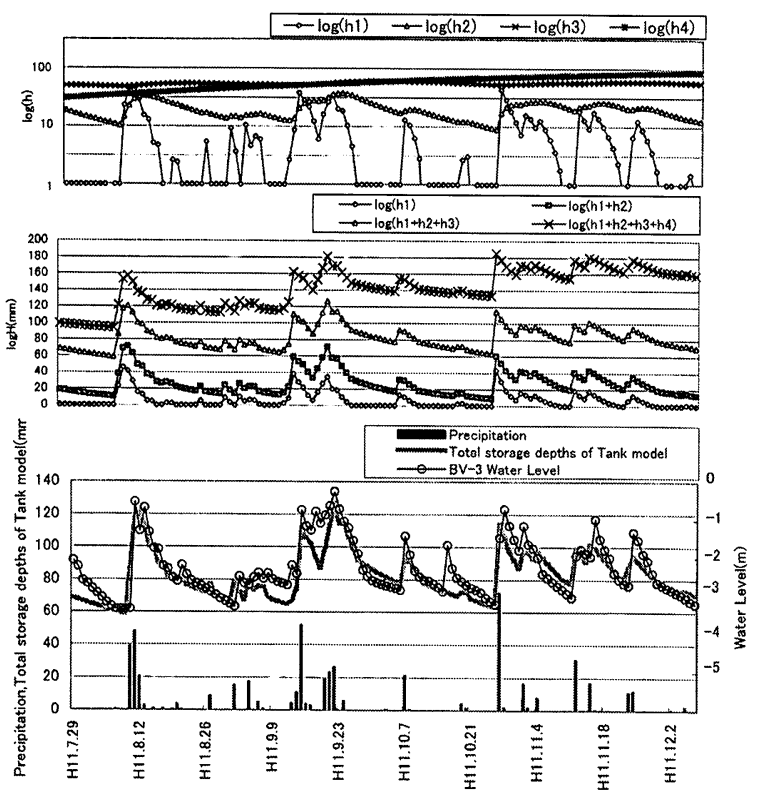

図一10 孔内水位ータンクモデル貯流高相関図

Fig. 10 Ground water level and total storage depths in T-Landslide

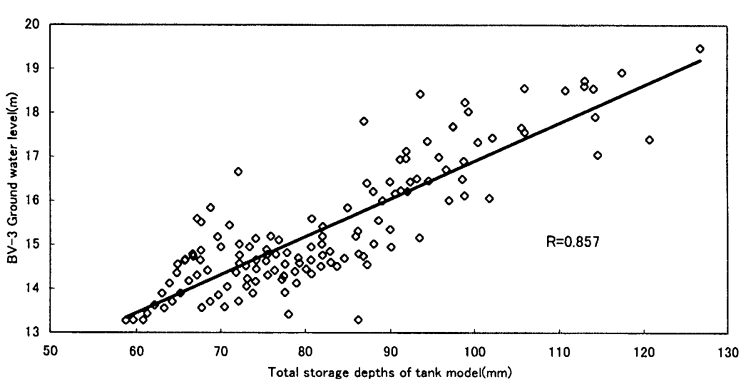

図ー11 T地すべりタンク貯流高一孔内水位相関図

Fig. 11 Total storage depths-Ground water level diagram of T-Landslide
計貯留高では 9 月 22 日において最も高く, ついで 8 月 11 日，10月27日の順となり，図－6に示される地すべりの 変位量の順と一致している。

次いで 1 日単位で設定されている菅原のタンクモデル 諸定数の流出係数, 浸透係数を時間単位に換算し, 地す ベり変位速度とタンクモデル合計貯留高の比較を行った 結果を図ー12に示す。時間単位のタンクモデルを用いる ことによって翌日のタンク貯流高には微妙な差が生じる が，降雨の影響は，翌時間には現れることとなる。ここ では 1 段目のタンク貯留高の要素の影響がもっとも強く 現れるため, 降雨のピークの直後に現れた地すべり変位 速度のピークとタンク合計譻留高のピークは, 図一 12 中 段に示されるように，合計貯留高ではいずれもほぼ一致 する形となった。図ー12下段のグラフに示すように，夕 ンク合計貯留高の対数值 $\log H=1.80$ を越える付近から 地すべりは散発的な滑動を示す傾向を見せ，更にタンク 合計畹留高の対数值 $\log H=1.90$ を越えると地すべり変 位速度とタンク合計貯留高は，図－13に示すようにべき 係数 5 程度のべき乗相関関係を示している1。
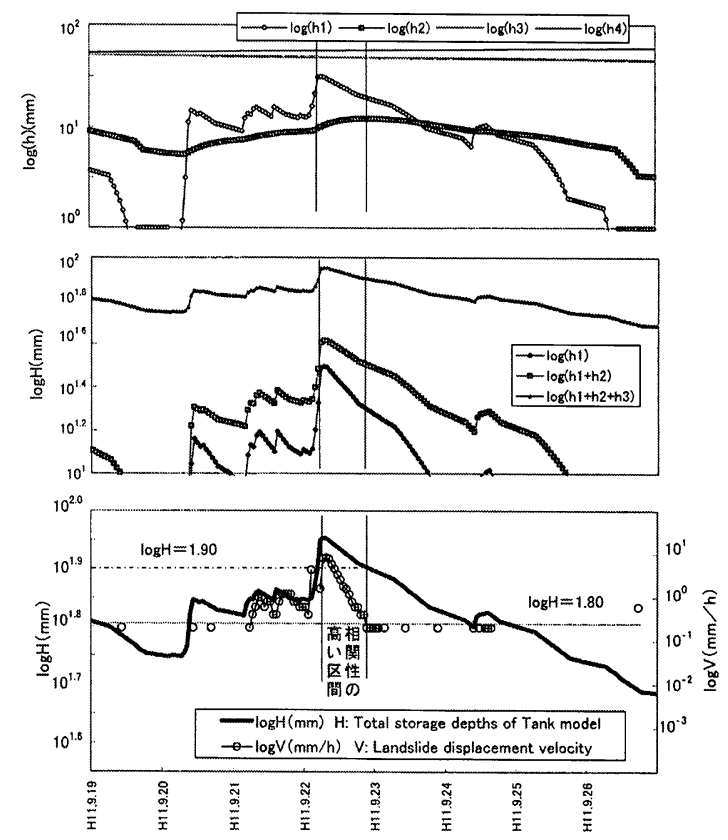

図-12 T地すべり $\log V-\log H$ 比較図

Fig. 12 Correlation between $\log V$ and $\log H$ in T-Landslide

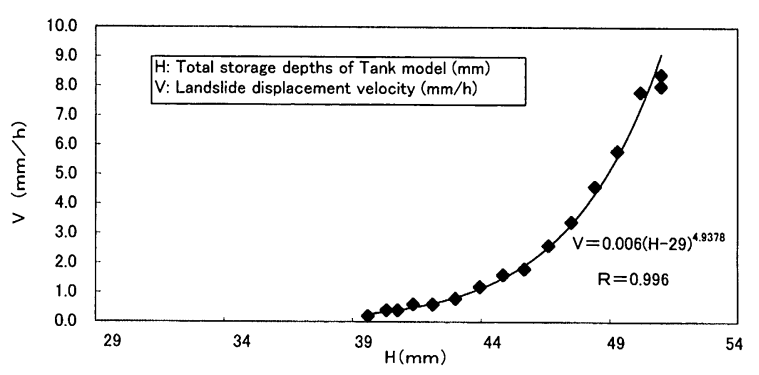

図-13 T地すべり $V-H$ 相関図

Fig. $13 \quad V-H$ diagram of T-Landslide 


\subsection{4 孔内水位と地すべり変位速度の 1 時間単位で の相関関係}

BV-3の 1 時間毎の孔内水位と 1 時間単位の地すべり変 位速度の関係を図ー14に示す。地すべり変位速度は降雨 のピークから $1 \sim 3$ 時間遅れで明暸に現れているのに対 し，孔内水位のピークは降雨のピークからは 5 時間以上 の遅れを示し，高原状のピークを示した後，なだらかな 低下を示している。ここでは孔内水位のピークよりも地 すべり変位速度のピークが 3 時間以上早めに現れている。

タンクモデル合計貯留高が図－12に示されるように地 すべり変位速度とほぼ同じピークを示しているのに対し， 孔内水位には数時間の遅れが見られる。本来，降雨に伴 い，孔内水位などを指標とする間隙水圧が上昇し，有効 応力の低下によって地すべりの安定度の低下を招くと考 えられているが，ここではこの関係が時間的に逆転して 現れている。このような現象が生じる原因には様々な要 因が推定される。例えば孔内水位は地すべり地塊におけ る水理地質状況の水平 - 垂直方向の異方性がある場合, 間隙水圧などの地すべりの安定に影響を及ぼす地下水の 状態を正確に表現しない場合があると考えられる。一方 でこの地区ではタンクモデルの合計貯留高は 1 日単位, 1 時間単位のいずれも地すべり变位速度の変化に追従す る指標としても有効に機能していた。

\section{4. 地すべり変位速度の 1 次クリープ的な指数関数的低 減現象}

\section{1 クリープについて}

クリープとは物体に一定の応力を作用させているとき に，歪みが時間と共に増して行く現象と定義される。歪 の経時的変化に着目すると，地すべり地に限らず一般的 な固体が理想的な弾性体，あるいは粘性体の挙動を示す 事は無く，クリープ変形を伴いながら両者の性状を併せ 持つ性質を示す。また，瞬間的な破壊を生じるに満たな い応力でも，長期間一定の応力が加わると，時間の経過 と共に歪みが増大し，ついには破壊にまで至ることが知 られている。この場合，作用する応力レベルによっても 異なるが，図－15に代表されるようなクリープ曲線が得 られる。一定の応力が作用すると，まず歪速度が時間と 共に減少して行く区間が現れ，これを 1 次クリープとし

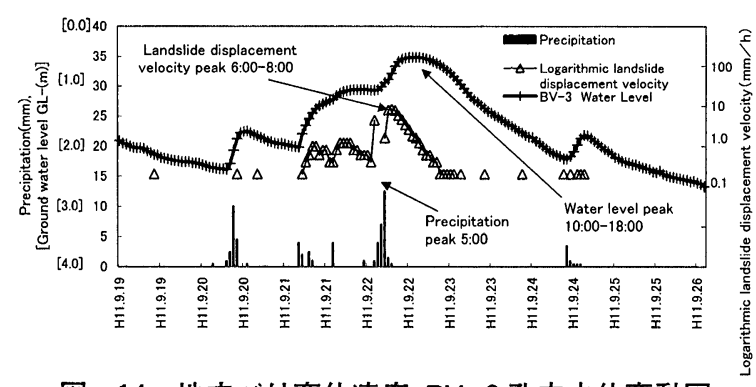

図-14 地すべり変位速度-BV- 3 孔内水位変動図

Fig. 14 Landslide displacement velocity and BV-3 water level in T-Landslide
ている。ついで，歪速度が一定の区間が現れ，これを 2 次クリープとしている。さらに歪速度が加速度的に増加 し，ついには破壊にまで至る区間が現れ，これを 3 次ク リープとしている。

\subsection{1 次クリープ}

ここで，1 次クリープは「クリープ速度が時間と共に 減少し，一定速度あるいは停止に至る現象」と定義され る。クリープ現象は金属や高分子化合物などの分野で研 究が進み，様々な構成式が提案されている。このような 1 次クリープ現象を最も単純なレオロジーモデルで代表 させようとすると，前述した図－2に示されるバネと ダッシュポットを並列させたフォークトモデルがまず挙 げられる。フォークト物体においては歪をととすると， スプリングとダッシュポットにおける応力はそれぞれ 及びทと்となり，それらの応力の和である。は

$\sigma=\kappa \cdot \varepsilon+\eta \cdot \dot{\varepsilon}$

$\varepsilon$ : 歪, $\dot{\varepsilon}:$ 歪速度, $\kappa$ : 物質定数, $\eta$ : 粘性率 で現され ${ }^{8)}, t=0$ で $\varepsilon=0$ の場合に一定の応力 $\sigma$ が加えら れれば微分方程式(1)の解は

$$
\varepsilon=(\sigma / \kappa)\left\{1-\exp ^{-\kappa \cdot t / \eta}\right\}
$$

とされる ${ }^{8}$ 。したがって歪み速度の時間的変化は

$$
\dot{\varepsilon}=-\sigma / \kappa \cdot \exp ^{-\kappa \cdot t / \eta}
$$

で表され，歪み速度を対数表示すると

$$
\ln \dot{\varepsilon}=-\kappa \cdot t / \eta \cdot \ln (\sigma / \kappa)
$$

となり，歪み速度を対数表示とする時間的な変動グラフ では，負の勾配の直線グラフで表されることとなる。

このように地すべり変位速度が 1 次クリープ的低減を 示す事例についての検討を行う。

\subsection{Y地区の事例}

\subsection{1 地すべり変位速度の変動状況}

7 月26日の地すべり発生直後より冠頭部に設置した伸 縮計の 1 日単位の観測結果を図-16に示す。観測開始当 初は $2 \sim 3 \mathrm{~mm} / \mathrm{d}$ の地すべり変位速度を保っていたが, 8 月 3 日の時間 $15 \mathrm{~mm}$, 連続雨量 $16.5 \mathrm{~mm}$ の降雨を契機

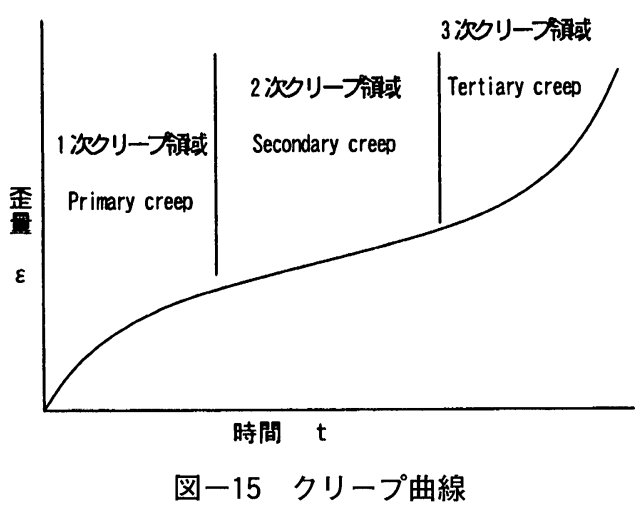

Fig. 15 Creep curve 
に一気に不安定化し，この直後の変位速度は $10.6 \mathrm{~mm} / \mathrm{h}$ にまで達した。その後数日は降雨も無く変位速度は一定 の割合で徐々に減少していたが，8月9日から10日にか けての連続雨量 $120 \mathrm{~mm}$ 契機に再び激しい活動を見せ, 時間変位速度は最大 $70.4 \mathrm{~mm} / \mathrm{h}, 2$ 日間にわたる変位量 は632.4mmに達した。しかしこの後は，豪雨時に大き な活動は示すものの, 降雨量に対する変位量の割合は相 対的に低下し，また降雨がやんだあとの地すべり変位速 度減速の割合は 8 月 3 日〜 9 日までに比較し明らかに大 きくなった。

\subsection{2 地すべり変位速度とタンクモデル貯留高}

タンクモデル貯留高と地すべり変位速度の相関性につ いての検討を行ったところ，菅原のモデルでは良好な相 関関係は得られなかったが，短期流出解析に用いられる 道上"9)の提示するタンクモデルの 1 段目のタンク貯留高 と地すべり変位速度の間に最も高い相関性が認められた。 1 時間単位での降水量・地すべり変位速度・1 段目の夕 ンク䝰留高を図ー17に示す。図ー17の上段，中断のグラ フに示されるように，2，3，4段目と譻留高を加える

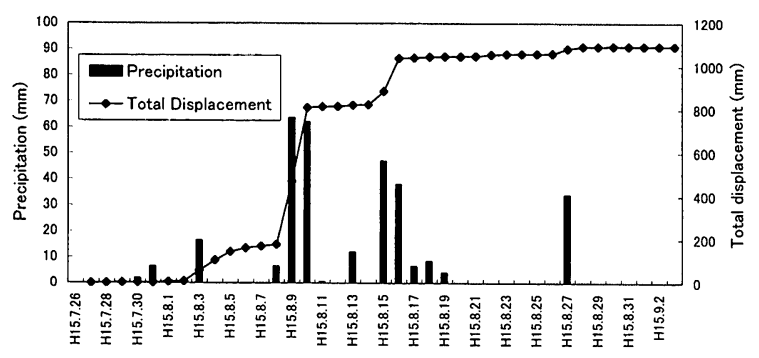

図一16 Y地すべり 地盤伸縮変動図

Fig. 16 Precipitation and total displacement in Y-Landslide
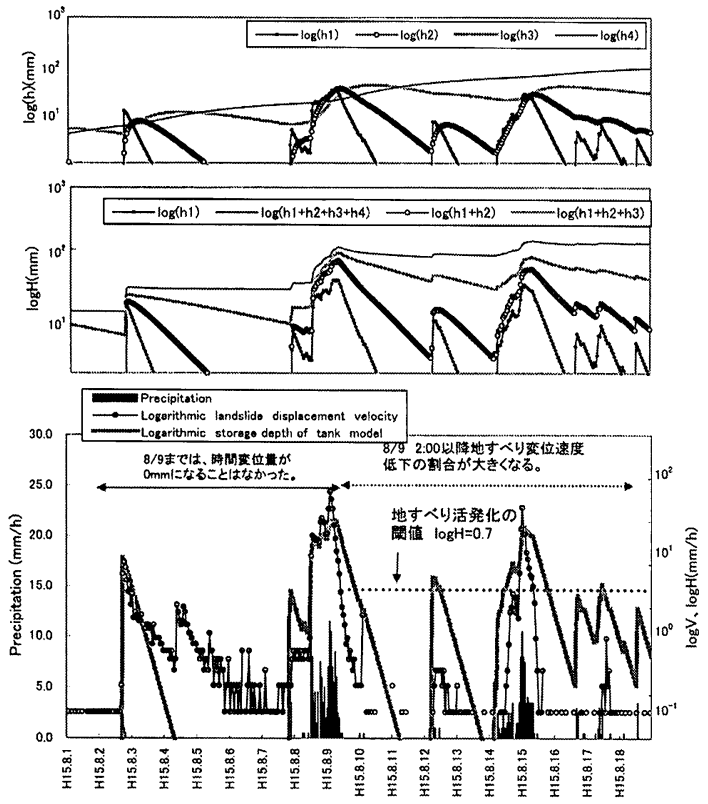

図一17 Y地すべり $\log V-\log H$ 比較図 1

Fig. 17 Correlation between $\log V$ and $\log H$ in Y-Landslide
ほど，降雨の影響は長時間に及ぶこととなり，地すべり 変位速度が急速に変化するY地区では，1段目のタンク 譻留高が地すべり変位速度と最も近い変動形態を示して いた。道上の示すタンクモデルは 3 段目までの合計眝留 高が土壤雨量指数の算定にも用いられている 1 時間単位 のモデルであり, 豪雨に伴う表層崩壊などとの関連が10) 指摘されている。1段目の貯留高は降雨に対する変動の 割合の最も急速な変化を示す部分であるが，当地区はす べり層厚が比較的薄くかつ急勾配であるためか，表土層 の含水量変化の影響を大きく被り，この結果タンクモデ ルの 1 段目の貯留高とも高い相関性が得られたのではな いかと考えられる。

ここで，地すべり変位速度とタンクモデル貯留高の比 率に急激な変化の生じていた 8 月 8 日から 9 日にかけて の変動状況を図ー18に示す。 8 月 9 日の午前 2 時まで 1 段目のタンクモデル䝪留高と地すべり変位速度は相似的 な変動を示していた。しかしこれ以降も5 時間にわたっ て $5 \sim 10 \mathrm{~mm} / \mathrm{h} の$ 降雨が継続し，1段目のタンクモデル 貯留高が高原状の高い值を保っているのに対し，地すべ り変位速度は一定の割合で急速な指数関数的低隇を見せ, 8 月10日 4 時にはほぼ停止し，変動パターンには大きな 変化が生じている。地すべり変位速度と 1 段目のタンク モデル䝪留高の比率を図ー19に示す。8月 8 日12時〜 8

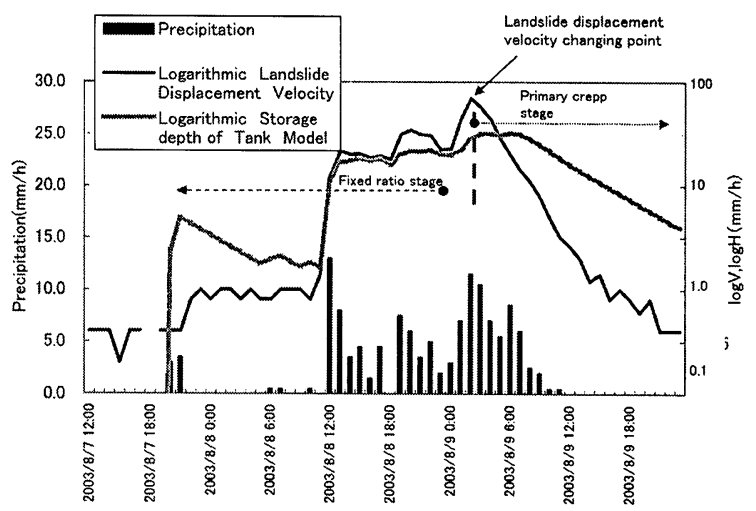

図一18 Y地すべり $\log V-\log H$ 比較図 2

Fig. 18 Correlation between $\log V$ and $\log H$ in Y-Landslide 2

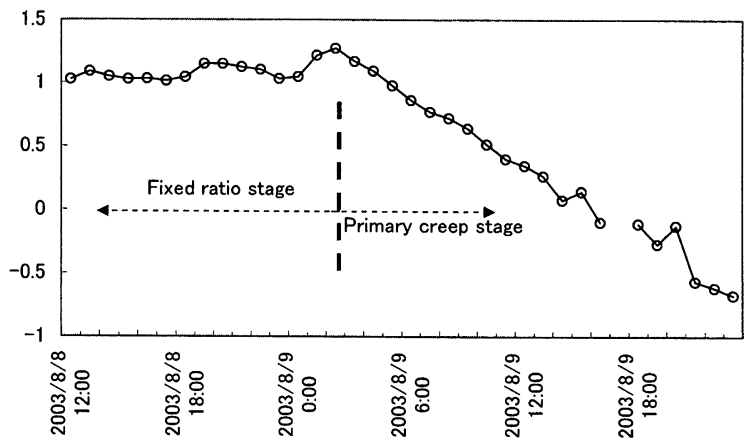

図-19 Y地すべり 地すべり変位速度 $(\log V) /$ タンクモデル貯留高 $(\log H)$ 変動図

Fig. 19 Change of landslide displacement velocity (log $V)$ /Storage of tank model $(\log H)$ ratio 
月 9 日 2 時の間, 両者の比率は $1 \sim 1.3$ の範囲で推移し ていたが，8月 9 日 2 時以降は一定の割合での規則的な 低減を示している。この現象は地すべり末端部で施工さ れていた抑え盛土工の効果が発揮し始めたことによると 考えられる。また, 当初は常時 $0.2 \sim 0.4 \mathrm{~mm} / \mathrm{h}$ 以上の速 度を維持していた地すべり変位速度が，図－17下段のグ ラフに示されるように，8月 9 日の 1 次クリープ的現象 以降はタンク貯留高 $\log H=0.7$ 程度を閾値としてこの 值以下では顕著な地すべり変動は認められなくなった。 なお，急増した地すべり変位速度の低減勾配も明らかに 増大している。この間，地すべりブロック末端部の地形 に顕著な変化は認められず，抑え盛土による効果が発揮 され，この過程では 1 次クリープ的現象を伴いながら地 すべり移動体の強度増加現象が生じていたと考えられる。 なお，このような規則的な地すべり変位速度の指数関数 的低減傾向は，当地における交通規制解除の判断にあ たっての重要な判断指標として用いられた。

\section{5. 考察}

5.1 地すべり变位速度の指数関数的低減現象について 地すべり現象は規模の大きな地塊の動きであり, 突然 動き出し，あるいは停止することはなく，この過程では 一定の規則性を伴っていると考えられる。一見断続的な 変動を見せていると思われる地すべり現象も，停止に至 る地すべり変位速度の減速域で顕著な指数関数的低減現 象を示していることがある。地すべり変位速度が指数関 数的低減を見せる地すべり現象には，降雨による不安定 化要因が指数関数的低減現象示す場合と，フォークトモ デルに代表されるような 1 次クリープ的要因に基づく 2 種類があると考えられる。
降雨による地すべり変位速度の変動は一般的なタンク モデルの最上段から幾段目かまでの合計貯留高と一定の 相関性が認められることがある。この椂な相関関係が確 認される場合, 観測される降雨量から逐次, 直接得られ るタンクモデル貯留高を, 地すべりの安定度の指標とし て用いることが可能となる。すなわち, タンクモデル貯 留高の增大時には警戒避難等の発令, 低減域には解除の 検討の有効な指標として用いることが可能となる。

さらに地すべり変位速度 $V$ とタンクモデル合計貯留高 $H$ の比率 $V / H$ の経時変化に着目することによって, 図 - 4 に示されるように 3 次クリープから崩壊に至る過程, 図ー18, 図-19に示されるような 1 次クリープを経て停 止に至る過程の識別が可能となる場合がある。地すべり 変位速度の増大する 3 次クリープと異なり， 1 次クリー プによる低減現象はタンクモデル貯留高に起因する低減 現象と重なり合うため, 1 次クリープ領域の判断は短期 的には困難な場合があるが，指数関数的低減現象が継続 している限りは，地すべりは基本的には安定側に向かっ ていると判断することは可能である。

\section{2 レオロジー面からの評価の必要性}

地すべりの安定を, すべり面のせん断強度のつりあい に対応するスライダーの要素だけで評価すると, 地すべ りの形状に大きな変化がなければ，押え盛土工などの施 工が完了した時点で地すべりは即座に停止することとな り，徐々に安定度が上昇して行くような現象を説明する ことは困難である。このような現象の説明にはフォーク トモデルに代表される1次クリープ的要素で説明する手 法がある。しかし，地すべり現象をレオロジーモデルで 表現しようとする場合，すべりせん断抵抗に対応するス ライダーの要素を省くことはできない。これを最も単純

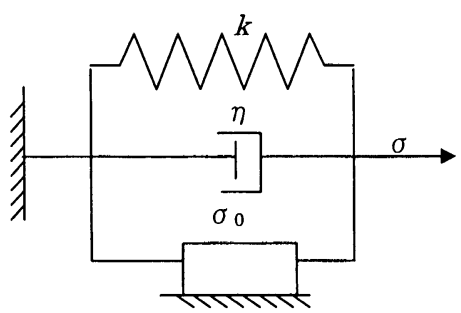

图ー20-a 1 次クリープレオロジーモデル Fig. 20-a Primary creep rheology model

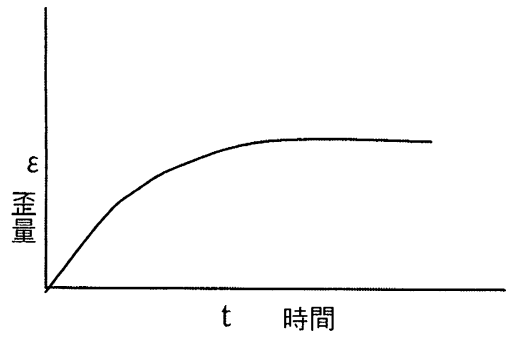

図ー21-a 1 次クリープ 歪一時間曲線 Fig. 21-a Primary creep strain curve

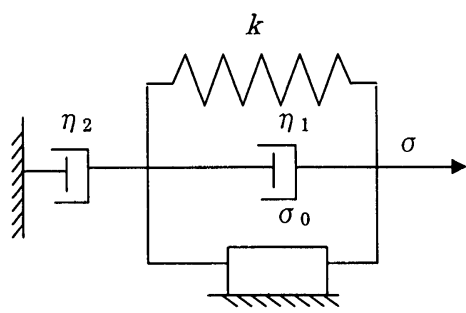

図ー20-b 2 次クリープレオロジーモデル Fig. 20-b Secondary creep rheology model

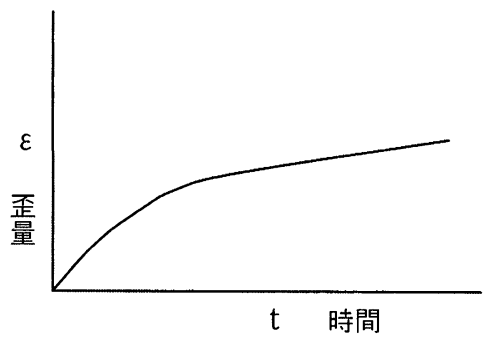

図ー20-b 2 次クリープ 歪一時間曲線 Fig. 21-b Secondary creep strain curve

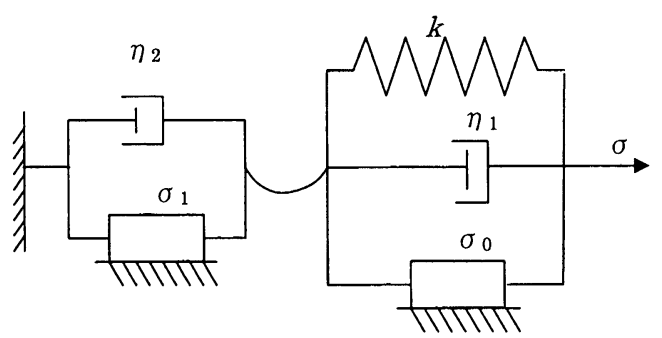

図ー20-c 歪硬化レオロジーモデル Fig. 20-c Strain hardening rheology model

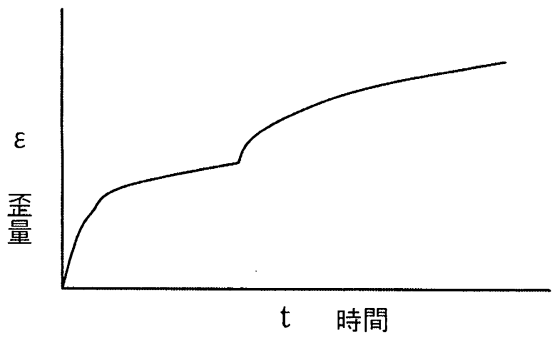

図ー21-c 歪硬化モデル 歪一時間曲線 Fig. 21-c Strain hardening strain curve 
な1次クリープ現象を現せば，図ー20-aに示される フォークトモデルにスライダーの要素が並列して加わっ たモデルが考えられる。何らかの要因で差応力 $\sigma=\Sigma T$ $\Sigma N>0$ となり, かつ差応力が一定の值を保つ場合には 図-21-aに示されるように歪速度は指数関数的低減を示 した後に停止するような 1 次クリープ現象を示すことと なる。次に，図ー20-bのようにこの背後にダッシュポッ 卜が加わると, 差応力 $\sigma>0$ でかつ一定の值を保つ場合 には図ー21-bに示されるような2 次クリープの挙動を 示す。ここでさらに差応力 $\sigma か ゙$ 降雨などの要因によって 変動する場合, 地すべり移動体がダッシュポットで示さ れるようにニュートン粘性体的挙動を示せば，歪速度は 差応力と線形の比例関係を示すこととなる。図ー4の 「相関性の高い期間」においてタンク合計貯流高と地す ベり变位速度の間に線形の相関関係の認められるS地区 はこのような事例であると考えられる。

次に, 電硬化のレオロジーモデルをJ. C. ジェーガー9 は図ー22に示すような緩んだ紐で連結されたスライダー のモデルで表現している。Y地区で見られるような降雨 などの外力変化の要因を取り除いても地すべり変位速度 が指数関数的低減傾向を示す現象は，図-20-cに示され るように更に歪硬化を担うスライダー $\sigma_{1}$ が加わったレオ ロジーモデルでの説明が考えられる。8月9日の 1 次ク リープ以降はスライダーの強度が $\sigma_{0}+\sigma_{1}$ に増加したこと によって地すべり活発化の閾値が増加し，1時的な地す ベりの停止も生じるようになった。また地すべり変位速 度が相対的に低下している現象はダッシュポットの粘性 率の增加で説明することも可能である。図 - 21-cはこの ような現象を模式化したものである。しかし，このよう な地すべり変位速度の規則的な低減現象が，地すべり移 動体における単純なバネの要素によるものか，あるいは スライダーで表現される部分に一定の比率での強度増加 が生じているのではないか，さらにはこれらの複合した 他の要因に基づくものではないか，といった疑問が残る。 いいかえれば，地すべり移動体のどの領域においてどの ようなメカニズムで強度増加が生じているのかを，より 具体的な物理モデルで説明することが求められ，さらに 事例を加え検討を進める必要がある。同様に差応力と歪 速度の関係が比例関係にあるニュートン粘性体の挙動を 示すかどうかは，図-13のようなべき乗の相関関係が見 られる事例もあり，今後様々な手法により検証を進めて 行く必要がある。

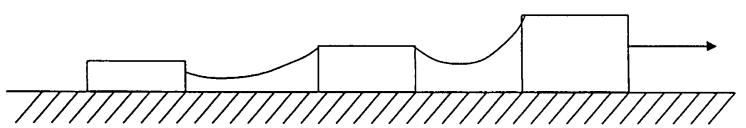

図一22 歪硬化モデル

Fig. 22 Strain hardening model

\section{6. まとめ}

地すべり現場において地すべり変位速度の変化に一定 の規則性が認められる場合，地すべり変位速度は地すべ り安定度の一つの指標となる。降雨に起因する地すべり 変位速度の変化とタンクモデル合計貯留高の間に一定の 相関関係が認められる場合のあることはすでに報告され ている1”。本研究ではさらにタンク合計販留高・ 孔内水 位・地すべり変位速度相互の関係について比較検討を 行った。この事例ではそれぞれに一定の相関関係が認め られた。タンク合計貯留高は急速な変化を見せる地すべ り変位速度にも対応可能な，降雨に起因する地すべり安 定度変化の有効な指標となることが確認された。また降 雨による要因とは無関係の, 一次クリープ的な地すべり 変位速度の指数関数的低減現象の存在が確認された。こ の現象の解明に当たっては，「すべり面強度」の経時的 変化について今後検討を進めてゆく必要があると考えら れる。

地すべりの安定に関する理論は, 地すべり変位速度が 何故変化し，またどのようなメカニズムで停止するのか といった動的な側面についても，一般的な物理法則など に基づく合理的な説明が求められる。地すべりは多様な 性状を有した規模の大きな移動体の变形現象であり，実 験室レベルだけでその実態を把握することは困難なこと がある。これらの現象の解明にあたっては，地すべり現 場において得られた観測デー夕などに基づく現象面から のアプローチも重要であり，さらに事例を加え，より詳 細な検討が求められる。また，この現象の物理学的な側 面からの解明も重要であり，レオロジー面からの定量的 な評価も試みる必要があると思われる。

\section{参考文献}

1) 神原規也（2002）：タンクモデルを用いた滑動中の地すべり安 定度評価, 地すべり, Vol. 38, No.4, pp.1-9.

2 ）駒村富士弥（1967）：地すべり土のレオロジー的特性とその特 性にもとづく地すべりの動き方について，地すべり，Vol.4， No. 2, pp. 10-20.

3 ）福本安正（1976）：地すべり粘土のクリープ特性(1)，地すべり, Vol. 13, No. 3, pp.6-13.

4 ）藤井弘章 外 (1995)：地すべり挙動の弾粘塑性有限要素解析, 地すべり, Vol. 31, No.4, pp.1-8.

5 ) 斎藤迪孝 (1968)：第 3 次クリープによる斜䤄崩壊時期の予知, 地すべり, Vol.4, No. 3, pp.1-8.

6 ）山田剛二・小橋澄治・草野国重（1971）, 高場山トンネルの地 すべりによる崩壊，地すべり，Vol. 8, No.1, pp.11-24.

7 ）菅原正已（1979）：続・流出解析法，共立出版。

$8 ）$ J. C. ジェーガー（1968）：弾性・破壊・流動論，共立出版、 pp. $107-108$

9 ) 道上正規・小島英司（1981）：集中家雨による崖崩れの発生予 測に関する研究, 鳥取大学工学部研究報告, Vol. 12, pp. 167 -178 .

10）牧原康隆・平沢正信（1993）：斜面崩壊危険予測における夕ン クモデルの精度, Journal of Meteorological Reseach, Vol.45, No. 2, pp. $35-70$.

（原稿受付2003年 9 月30日，原稿受理2004年 3 月31日） 